\title{
Teaching involvement in higher current education
}

Often we talk about the effects of globalization on social determinants. The great nations of the world come together to make the best decisions to continue life on the planet, being that educational institutions must take awareness of the role that concerns them and transcend to their graduates social responsibility and ethics that concerns them as citizens, able to work at different levels of complexity to address the individual and collective health, respecting differences: social, cultural, ethnic, among others, caused by the phenomenon of the global village, which brings changes in the health of populations most vulnerable, translated into the reemergence of diseases and other emergency that still cannot be controlled; with changes in the epidemiological board, reaching the top: chronic diseases, influenced by unhealthy life styles of the same system takes to adopt, depending on demands of performance and speed of modern times, in which the market work requires a highly skilled labor, but at the same time very cheap and deeping the exploitative and discriminatory the same character. ${ }^{1,2}$

Against that, the higher education provided in this century must normalize within an ethical framework that may lead a person to assume commitment in the CARE -the sometimes obsolete- sees itself, then to transfer it to others. Vieira quoted by Angel, ${ }^{3}$ refers about the phenomenon of globalization is expressed through five dimensions, standing here only two: 1) the social dimension, affected by the economic dynamics and translated into hunger, and social injustice and exclusion 2) environmental dimension, generated by the power of those who defend particular interests, endangering all life expression; Both aspects allows to reflect on the importance of the formation of the person, able to make decisions, and act aware of their responsibility in caring for life. Care, as Boff says, quoted by Angel, ${ }^{3}$ must be developed as an attitude, understood as an ethical position of respect, based on principles of solidarity, generosity, love and virtues that reflect the moral character that encloses the care.

In this perspective, the exercise to care is a duty of universal character, transcending cultures and traditions and which highlights the degree of humanity. This exercise is also applied in the classroom, teaching nursing, which should be focused on what is the essence of the actions of the profession: The CARE.

In this century, care becomes a challenge because the world has become complex, to understand it has been broken up into parts that obstruct the holistic approach with it should be observed the human being (person-user-community). In the formation of the future professional nursing it seeks to preserve that integrity, although still domain the biomedical model and practices are aimed at developing technologies and protocols; which certainly seek to improve the health of the person; but also distracting the attention and take away an important aspect of the essence of care: $:^{5}$ let it be, through the preservation of their identity, sharing their sorrows, anxieties, joys and expectations, without any effort becomes apparent, so that patient feels safe and confident in the person next to him (professional), who understands how much more complex is reality, more care must be made.

During the formation of the nurse must permeate in students "something more" than just knowledge and procedures, ${ }^{6}$ which is formed by the values and principles so much required in this millennium to define behavior and assertive attitudes, flowing natural and dignified manner practiced by whom and who receives them. However, to join nurses into the workplace, they enter a normalized system, which tends to dehumanize care, either by accomplishing goals or protocols that universalize interventions ${ }^{7}$ assuming many times that quality is synonymous with increased production and less investment. 
This reality forces quickly address changes in higher education, with the student's learning process and the conditions that make it possible transcendentals; understanding that among these conditions is the role of teachers, whose responsibility is to be committed to human development of others and of themself, who face challenges in making decisions at an institutional system and culture that might be contrary to the vision. Therefore, educating citizens with commitment is imperative, because the ecosystem is comprised of all and together they all contribute to global health; Thus, in addition to open standards for knowledge, it must be emphasized attitudinal aspects that reflect the interest towards the other, in other words, in the values, especially moral, because they are those that will allow strengthen the other values. In this case, civic values, such as freedom, equality, solidarity and readiness for dialogue ${ }^{8}$ values that facilitate the coexistence with others, in a wake of humanism and multiculturalism, so essential in today's times.

Correspond to those involved in the art of forming the future professional nursing, weaving education with threads of love, understanding and empathy; this process in an atmosphere of trust, friendliness and security, that being to develop in all his humanity, keeping their personal identity, authenticity and nature.

It is necessary to understand the nature of mankind, as the spirit that is within a subject; gifted and willing qualities of rescue, through a system based on the conviction service submission and humility in front the great force of creation, recognizing that every human being is just an instrument that reflects the infinite love.

\section{BIBLIOGRAPHIC REFERENCES}

1. Feo IO. Reflexiones sobre la globalización y su impacto en la salud laboral y ambiental. Ciencia \& Salude Coletiva [serie de internet], 2003 [citado 02 de feb 2015]; 8(4): 887-96. http://www.scielo.br/scielo.php?pid=S1413-81232003000400011\&script=sci_arttext

2. Prado ML, Reibnitz KS. Salud y globalización: retos futuros para el cuidado de enfermería. Invest Educ Enferm [serie de internet]. 2004 [citado 15 de feb 2015]; 22(2): 104-11. . http://aprendeenlinea.udea.edu.co/revistas/index.php/iee/article/viewFile/2964/2675

3. Vargas LA, Andrés JPT, Oliveira TFV, Las relaciones entre la globalización, Medio ambiente y Salud: Retos para la enfermería en el siglo XXI. Index Enfern [serie de internet]. Sep 2010 [citado 15 de feb 2015]; 19(2-3):[aproximadamente 07 laudas]. Disponible en: http://scielo.isciii.es/scielo.php?script=sci_arttext\&pid=S1132-12962010000200018

4. WaldowVR. Enseñanza de enfermería centrada en el cuidado. CHIA [serie de internet]. Dic 2009 [citado 02 de mar 2015]; 9(3): 246-56. Disponible en: http://aquichan.unisabana.edu.co/index.php/aquichan/article/view/1523/1970

5. Troncoso MP, Suazo SV. Cuidado Humanizado un desafío para las enfermera en los servicios hospitalarios. Acta Paul Enferm [serie de internet]. [citado 02 de mar 2015]; 20(4): 499-501. Disponible en: http://www.scielo.br/pdf/ape/v20n4/18.pdf

6. Ceballos VPA. Desde los ámbitos de enfermería, analizando el cuidado humanizado. Ciencia y Enfermería [serie de internet]. 2010 [citado 15 de ene 2015]; XVI (1): 31-5. Disponible en: http://www.scielo.cl/pdf/cienf/v16n1/art_04.pdf

7. Arredondo-Gonzales CP, Siles-González J. Tecnología y humanización de los cuidados. Una mirada desde la teoría de las relaciones interpersonales. Index Enferm [serie de internet]. Ene-mar 2009 [citado 13 de ene 2015]; 18(1): [aproximadamente 07 laudas]. Disponible en: http://scielo.isciii.es/scielo.php?pid=S1132-12962009000100007\&script=sci_arttext

8. Cortina A. Ciudadanos del mundo, hacia una teoría de la ciudadanía [internet]. Madrid-España: Alianza Editorial; 2001 [citado 10 de dic 2014]. 36 p. Disponible en: http://www.culturadelalegalidad.org.mx/recursos/Contenidos/Estudiosacadmicosyestadsticos/document os/Ciudadanos20del20Mundo,20Adela20Cortina.pdf 